\title{
Abbreviations and Translations
}

All citations of Kant's writings are to the so-called Akademie edition (Kants Gesammelte Schriften, ed. Königlich preussischen [later, Deutschen ] Akademie der Wissenschaften [Berlin and Leipzig: Walter de Gruyter, 1900- ). All translations are mine. Page numbers following them refer readers to the relevant sections of the translations cited below. To minimize the citations that appear in the text, all references to Kant's work in German in the first section are to pages in the first volume of the Akademie edition, unless a roman numeral indicates another volume, and all the English translations, unless another work is indicated in parentheses, refer to the only complete translation of the work under constant scrutiny, namely, the Universal Natural History and Theory of the Heavens, trans. Stanley L. Jaki (Norwich, Scotland: Scottish Academic Press, I98I). All references in the second section to Kant's work in German are to the eighth volume of the Akademie edition, unless a roman numeral appears; unless otherwise indicated, the reader is further referred to the most accurate translation of the primary texts under consideration, that is, to Perpetual Peace and Other Essays, intro. and trans. Ted Humphrey (Indianapolis: Hackett Publishing Company, 1983). All references in the third section to Kant's German text are to the seventh volume of the Akademie edition, unless a roman numeral appears; the page number of the only complete translation of the Conflict of the Faculties, intro. Mary J. Gregor, and trans. Mary J. Gregor and 
Robert E. Anchor (New York: Abaris, 1979) are also given in parentheses. All citations of the Critique of Pure Reason, both in English and in German, refer to the original pagination of the first and second editions (designated " $A$ " and " $B$ " respectively). The standard English translation is that of Norman Kemp Smith (New York: St. Martin's Press, 1965). The following abbreviations refer to the other standard English translations used throughout the book:

APP Anthropology from a Pragmatic Point of View, trans. Mary J. Gregor. The Hague: Nijhoff, 1974.

CF The Conflict of the Faculties, intro. Mary J. Gregor, trans. Mary J. Gregor and Robert E. Anchor. New York: Abaris, I979.

CJ Critique of Judgment, trans. Werner S. Pluhar. Indianapolis: Hackett, I 987.

CPR Critique of Practical Reason, trans. Lewis White Beck. Indianapolis: BobbsMerrill, I 956.

DSS Dreams of a Spirit Seer, trans. and intro. John Manolesco. New York: Vantage, I 969.

DV Doctrine of Virtue, trans. and intro. Mary J. Gregor. Philadelphia: University of Pennsylvania Press, I964.

FMM Foundations of the Metaphysics of Morals, trans. and intro. Lewis White Beck. Indianapolis: Bobbs-Merrill, 1959.

KLW Kant's Latin Writings, ed. Lewis White Beck, trans. J. A. Reuscher, Ralf Meerbote, Mary J. Gregor, L. W. Beck, and John Handyside. New York: Peter Lang, 1986.

LE Lectures on Ethics, trans. Louis Infield. Indianapolis: Hackett, I 963.

MEJ Metaphysical Elements of Justice, trans. and intro. John Ladd. Indianapolis: Bobbs-Merrill, I 965.

MFS Metaphysical Foundations of Natural Science, trans. James W. Ellington. Indianapolis: Hackett, 1985.

OF Observations on the Feelings of the Beautiful and Sublime, trans. J. T. Goldthwait. Berkeley: University of California Press, I 965.

$\mathrm{OH}$ On History, ed. Lewis White Beck, trans. L. W. Beck, Robert E. Anchor, and Emil L. Fackenheim. Indianapolis: Bobbs-Merrill, 1963.

OPB The One Possible Basis for a Demonstration of the Existence of God, trans. Gordon Treash. New York: Abaris, 1979.

PC Philosophical Correspondence, ed. and trans. Arnulf Zweig. Chicago: University of Chicago Press, 1967.

PFM Prolegomena to Any Future Metaphysics, trans. Paul Carus and James W. Ellington. Indianapolis: Hackett, 1977.

PP Perpetual Peace and Other Writings, ed. and trans. Ted Humphrey. Indianapolis: Hackett, 1983.

RLR Religion within the Limits of Reason Alone, trans. and intro. Theodore $\mathrm{M}$. Greene and Hoyte H. Hudson. New York: Harper \& Row, I960.

UNH Universal Natural History and Theory of the Heavens, trans. Stanley L. Jaki. Norwich, Scotland: Scottish Academic Press, I98I.

WPM What Real Progress Has Metaphysics Made in Germany since the Time of Leibniz and Wolff? trans. Ted Humphrey. New York: Abaris, 1983. 